\title{
EL MENSAJE DEL REMANENTE EN EL TIEMPO DEL FIN: EL MENSAJE DE LOS TRES ÁNGELES EN APOCALIPSIS 14:6 - 12 - Parte II
}

\author{
Oscar Mendoza Orbegoso \\ FACULTAD DE TEOLOGIA - UPEU
}

\section{Introducción}

En el artículo anterior se concluyó que el término "ángel” en Apocalipsis 14:6-12, ${ }^{1}$ representa a un movimiento que cumple la misión en el tiempo del fin. Dicho movimiento es el remanente de Apocalipsis 12:17, ${ }^{2}$ por el contexto escatológico en el que aparece. También se estudió tres verdades extraídas del Mensaje de los tres ángeles (en adelante Mta), las cuales fueron: (1) el evangelio eterno, (2) la santificación y (3) el juicio pre advenimiento.

El propósito del presente artículo es estudiar las otras seis verdades, especialmente del segundo y tercer ángel, y las implicancias que existen entre ellas.

Este ensayo será abordado desde la perspectiva contextual - bíblica, analizando cada una de las verdades que se encuentran en el Mta.

\section{El creacionismo}

El mensaje del primer ángel también invita al mundo a "adorar al Creador". ${ }^{3}$ No obstante, éste no es un simple llamado a adorar; éste

${ }^{1}$ Los textos serán citados de La Biblia de las Américas (La Habra, CA: The Lockman Foundation, 1997).

${ }^{2}$ Para un mayor estudio sobre el remanente, ver Ángel Manuel Rodríguez, ed., en Toward a Theology of the Remnant (Silver Spring, MI: Biblical Research Institute, 2009); Carmelo L. Martínez, "El concepto del remanente en la Iglesia Adventista del Séptimo Día: razones subyacentes en el debate contemporáneo" (Tesis doctoral, Universidad Adventista del Plata, 2002); Ekkehardt Müeller, "The End Time Remnant in Revelation", Journal of the Adventist Theological Society 11, no. 1-2 (2000): 188-204. En adelante JATS.

${ }^{3}$ Esta acción también implica guardar sus mandamientos y cuidar la creación. 
implica: (1) adorarle únicamente a él, (2) adorarle en su día y (3) aceptar el relato literal de la creación. ${ }^{4}$

\section{Adorarle únicamente a él}

En un mundo donde el centro del universo y del conocimiento es el hombre, y en algunas religiones la naturaleza, el remanente proclama: "Adorad al Creador". Este mensaje reconoce a Dios como el originador y el sustentador de las cosas (Heb 1:3). Como tal, la honra y la gloria son únicamente para Él; esto implica que ni el hombre ni la naturaleza deben de autoproclamarse el centro del universo, mucho menos autoadorarse o dejarse adorar o ser instrumento de adoración (Is 40:25). Este mensaje invita a adorar únicamente al Creador y no a la creación.

En el contexto escatológico, que Dios sea el centro de la humanidad y no la creación es relevante, puesto que las dos bestias de Apocalipsis 13, que son poderes humanos, exigirán adoración. Para lograr este objetivo, la 1ra bestia demandará que le adoren (vv. 3-5, 12-15) y la 2da hará "grandes señales", supuestamente divinas, con el fin de engañar a los moradores de la tierra (vv. 13-14) y así honrar a la primera. Frente a esta actitud, el remanente invita: "Adorad al Creador y no a la bestia, puesto que todo lo creado viene de Dios y es Él quien debe de ser adorado; no un ser humano, tampoco una imagen, mucho menos un muerto. Toda alabanza, obediencia y oración han de ser dirigidas al Ser que nos creó, nos redimió y nos sustenta; y no a ningún ser creado, por más obrador de milagros que sea".

Teniendo en cuenta esto, la batalla final tendrá como base las siguientes preguntas: ¿Quién es el centro del universo? ¿Quién debe ser adorado: las bestias espantosas de Apocalipsis 13 quienes hacen "señales prodigiosas" o Dios quien hizo "los cielos y la tierra"?

${ }^{4}$ Para el primer mensaje, como síntesis de esta sección, no existe ni evolucionismo ni la vida después de la muerte. Ambos puntos de vista contradicen la creación de Dios tal cual es presentada en las Escrituras. Por un lado, el evolucionismo trata de contrariar el inicio de la vida; por otro lado, la inmortalidad del "alma" el fin de ella.

${ }^{5}$ Para un estudio sobre la adoración a la bestia en Apocalipsis 13, ver Oscar Mendoza Orbegoso, "Alusiones al sábado en Apocalipsis 12 al 14", Berit Olam 7, no. 1 (2010): 192-7. 


\section{Adorarle en su día}

Existe una conexión entre el mensaje "adorad al que hizo el cielo y la tierra, el mar y las fuentes de las aguas" del primer ángel, y el decálogo de Éxodo 20:4, 11. ${ }^{6}$ Ésta genera una relación entre la adoración, el 2 do y el 4to mandamientos, lo que implica adorar a Dios en el día que él estableció como santo, a saber, el sábado; día que, según las Escrituras, es un memorial de la creación (Éx 20:8-11) y la redención (Dt 5:12-15) del hombre.

Como memorial de la creación, en este día toda persona recuerda que vino a la existencia por obra de un Creador, y que lo que él es y tiene, es gracias al infinito amor de Dios al darle y sustentarle la vida; por esta razón, la adoración es exclusivamente para él. Por el contrario, si el hombre no guarda el día de reposo, corre el peligro de: (1) negar la existencia de un Creador, (2) rechazar la omnipotencia de Dios y así negar la creación hecha de la nada y en seis días literales, (3) auto adorarse o adorar a otro ser, ya sea vivo o muerto, (4) independizarse de Dios, (5) rebelarse contra su Creador y obedecer únicamente al ser humano, (6) olvidar el futuro esperanzador que Dios tiene para sus hijos y (7) no relacionarse correctamente con Dios ni con la familia. Con estos riesgos, la persona que no guarda el sábado puede convertirse en ateo, evolucionista, evolucionista teísta, humanista, posmodernista, etc. Por estas razones, es importante reposar el día que él lo instituyó como un memorial de la creación.

Como memorial de la redención, el día sábado también es un recordatorio de los actos salvíficos de Dios. Observarlo ha hecho recordar que el único que nos ha librado de la esclavitud del pecado es nuestro

${ }^{6} \mathrm{Al}$ respecto, J. M. Ford declara, "el ángel heraldo en 14:6, 7 anuncia la reafirmación del decálogo y la adoración de un solo Dios, en oposición a la adoración de la imagen (13:15) el cual violó los mandamientos. La referencia a Dios como Creador es entendido en la luz de la referencia al cielo, tierra, y el agua debajo de la tierra en Éxodo 20:4" (Revelation, en The Anchor Bible, eds. I. Howard Marshall y Donald A. Hagner [Nueva York: The Anchor Bible Doubleday, 1975], 38:248). De igual manera, Ekkehardt Müeller comenta, "lo escrito en 14:7 especifica el cuarto mandamiento. Adorar a Dios como Creador también implica guardar su día santo, el día que Él instituyó en la creación como una conmemoración de la creación" ("The End Time Remnant in Revelation", JATS 11, no. 1-2 [2000]: 194). Asimismo, los editores de la 4ta edición del Griego del Nuevo Testamento notan en el margen que Apocalipsis 14:7b es una alusión a Éxodo 20:11. Ranko Stefanovic, Revelation of Jesus Christ, Commentary on the Book of Revelation (Berrien Springs, MI: Andrews University Press, 2002), 416. 
Creador y, como tal, tiene que ser adorado. En cambio, si se deja de lado el 4to mandamiento y no se lo guarda, probablemente: (1) creamos que la salvación es sólo por las obras; (2) pensemos que nosotros mismos nos podemos salvar del pecado; (3) no recordemos quiénes somos y volvamos a nuestra antigua manera de vivir; (4) pensemos que la 2 da venida de Cristo tendrá como propósito destruir y no redimir; (5) dejemos de depender de Dios para nuestra salvación y (6) nos olvidemos de la misericordia que profesamos como cristianos. Por eso, cuán importante es reposar el día sábado tal cual lo presenta las Escrituras. Al observarlo, evitará tener un pensamiento exagerado de la ley, impedirá que seamos orgullos creyendo que somos salvos por nuestras obras e imposibilitará la decepción y amargura, puesto que aumentará nuestra esperanza para una vida mejor en el presente y en el futuro.

Por estos dos motivos es que Dios es adorado: él es nuestro Creador y Redentor. Esta adoración, como respuesta a sus actos creativos y salvíficos, se ha de realizar de la manera como él pide, a saber, guardando sus mandamientos, incluyendo el cuarto.

Como memorial que es el 4to mandamiento, tiene dos objetivos: (1) adorar a nuestro Creador y Redentor y (2) recordar sus acciones en nuestro favor. Son por estas razones que Satanás siempre ha tratado de abolir el sábado; y en la crisis venidera él intentará hacer lo mismo. Él querrá que la creación únicamente adore a la bestia que sube del mar en el día impuesto por él y que no adore a Dios en el día que él estableció.

\section{Aceptar el relato literal de la creación según las Escrituras}

La creación, tal como es presentada en la Biblia, ha estado en tensión en las últimas décadas. Si bien es cierto el adventismo cree en la creación en seis días literales, tal cual es enseñada en Génesis 1 y 2, hoy en día algunos han rechazado esta verdad. Paradojamente, también el catolicismo y buena parte del mundo protestante objetan lo que realmente dice las Escrituras acerca de la creación.

El concepto, a parte de la evolución de la especies presentada por Charles Darwin en 1844, que está en boga y que ha generado tensión en el adventismo, es El evolucionismo teísta. Esta teoría enseña que, si bien es cierto Dios creó la materia, él se valió de la evolución, como método 
de creación, para crear al ser humano y a la naturaleza. Esta evolución, la cual implica la ley de la supervivencia y por ende la muerte y la destrucción, duró miles de años produciéndose así la creación; por tanto, la creación en seis días literales no es aceptable. Sin embargo, este concepto genera muchas interrogantes e interpretaciones que están lejos de lo que declara las Escrituras. Por esta razón, es importante evaluarla y ver qué implicancias trae aceptarlo. Reflexionemos:

¿Es posible que un ser perfecto como Dios, cree seres imperfectos, para que éstos, evolucionando, se perfeccionen?

¿Es aceptable que Dios, quien es amor y actúa en base a este (1 Jn 4:8), utilice la muerte y la destrucción como métodos de creación, y luego pida a sus criaturas "permaneced en mi amor" (Jn 15:9, 10)?

¿Es sostenible que el Señor, siendo omnisapiente y omnipotente a la vez, haya demorado miles de años en hacer la tierra, si él, con dicho poder, pudo y puede crearla en tan sólo un día, en una hora, y hasta en un minuto? ¿No declara el Salmo 19:4 que Dios creó la tierra únicamente con su voz? ¿Cómo es que el omnipotente Creador usó la evolución para la existencia de la creación?

$¿$ Cabe la posibilidad de que Dios, quien es santo y no tiene nada que ver con el pecado y con la muerte, utilizó y permitió el desorden y la destrucción para que su creación evolucione? ¿No dicen las Escrituras que "la paga del pecado es la muerte" (Ro 6:23) y que el originador de éste es Satanás (Is 14:12-14)? Además, ¿Cómo Dios va castigar al pecador con la destrucción final (Ap 20:14-15), si ésta fue usada por Él en la creación? ${ }^{7}$

Si el Creador utilizó la evolución, que implica destrucción y muerte, esto haría pensar que el hombre no fue el causante del pecado ni de la muerte en la tierra sino el mismo Dios. Y si la raza humana no fue la responsable del pecado ¿De qué se lo va a juzgar? Y si la muerte y la destrucción estuvieron antes de la creación ¿De qué se le va a librar? ¿De la muerte, de la destrucción; si, después de todo, estos dos componentes son parte de la metodología de Dios para crear?

${ }^{7}$ Para un mayor estudio, véase Norman Gulley, “¿Es el Génesis un relato literal de la creación?”, en Volviendo a los orígenes: entendiendo el Pentateuco, VI simposio bíblico-teológico sudamericano, ed. Merling Alomía et al. (Lima: Theologika, 2006),53-60. En adelante VLO. 
Si la muerte y la destrucción existieron antes del pecado, entonces ¿Para qué vino Cristo a morir por el ser humano si nosotros no somos responsables de todo esto? Además, ¿No dicen las Escrituras que la muerte de Jesús tenía como objetivos "salvar lo que se había perdido" (Jn 3:17) y "desenmascarar al responsable de la muerte, a saber, al Diablo" (1 Jn 3:8; Heb 2:14)? Si la muerte y la destrucción estaban dentro de los planes de Dios para la creación, entonces, la muerte de Cristo no salvó a nadie y al único que se desenmascaró fue a Dios. ${ }^{8}$

Si los días de la creación duraron miles de años, por lo tanto, el séptimo día también tendría que durar mil (es) de años. Si es así, ¿Cómo es posible que Dios ordene guardar el séptimo día y prepararse un día antes para reposarlo (Éx 20:8-11; 16)?

Si el Señor demoró miles de años para crear los cielos y la tierra, entonces, también se demorará miles de años para crear los "nuevos cielos y la nueva tierra” (Ap 21:1), puesto que también utilizará el mismo método con el cual creó por primera vez la tierra. Asimismo, ¿Cuán esperanzador será el reino eterno que Dios creará si en su primera creación utilizó la destrucción y la muerte como método? De hecho, toda esperanza de un mundo mejor quedaría en la nada.

Como se vio, el evolucionismo teísta afecta las verdades bíblicas de la creación, la salvación, la 2 da venida, el pecado, la naturaleza del hombre, la ley de Dios, el sábado, el juicio divino, el gobierno y el reino eterno de Dios, etc. Por tal motivo, aceptar esta teoría es poner en tela de juicio la veracidad de la Palabra de Dios y presentar a la Biblia como un libro lleno de contradicciones y especulaciones acerca de nuestros orígenes, nuestra salvación y nuestro futuro. Sobre todo, distorsiona la imagen de amor y de justicia de nuestro Dios. ${ }^{10}$

\section{${ }^{8}$ Gulley, 55-8.}

${ }^{9}$ Sin duda, la orden de reposar el día sábado determina que los días de la semana de la creación también fueron de 24 horas y no millones de años como plantea el evolucionismo "teísta".

${ }^{10} \mathrm{El}$ evolucionismo teísta no tiene nada de teísta. Al contrario, es ateísta totalmente. Si esta teoría fuera teísta, ¿Por qué presenta una imagen tan distorsionada de Dios? No hay duda, al aceptar esta teoría, el ser humano llegará a rechazar al Creador y a su naturaleza como Ser divino. Para una defensa bíblica del creacionismo frente al evolucionismo teista, ver Marco Terreros, "Death before the Sin of Adam: A Fundamental Concept in Theistic Evolution and Its Implications for Evangelical 
Por estas razones, sólo queda objetarla.

Teniendo en cuenta esto, "adorar al Creador" también implica aceptar el relato literal registrado en Génesis 1 y 2. En estos tiempos, no basta obedecer sus mandamientos sino también aceptar lo que declara las Escrituras, a saber, que la creación no vino de ninguna especie o materia anterior, mucho menos de una gran explosión. Tanto la naturaleza como el ser humano fueron creados por Dios en seis días de 24 horas y no en cientos ni miles de años.

En una época, donde el mensaje bíblico de la creación está siendo distorsionado y atacado por distintos pensamientos y religiones, el remanente proclama: "El ser humano fue creado por Dios y no vino de la naturaleza, puesto que ella también vino de Él. Tanto cielos y tierra fueron hechos por su Palabra en seis días literales y no en un lapso de tiempo mayor. Por ser nuestro Creador, a Él se le tiene que adorar; no a la bestia ni a su imagen, sino a Él. Aquella adoración al Creador se manifestará a través de la observancia de los diez mandamientos, especialmente la del día de reposo".

\section{Segundo mensaje angélico (14:8)}

En este mensaje hay una verdad bíblica: la caída de Babilonia. Ésta implica el juicio condenatorio a "Babilonia" y la advertencia a salir de ella (Ap 18:4).

\section{La caída de "Babilonia la grande"}

El remanente también proclama la "caída de Babilonia". En esta sección se estudiará: (1) su identidad y (2) el significado de su caída.

Theology" (Thesis Ph. D., Andrews University, 1994); Norman R. Gulley, "Creation: The Foundational Importance of Scripture as Revelation", JATS 15, no. 1 (2004): 91-124. Ibid., "El desafío de la evolución teísta a la doctrina bíblica de la creación", Theologika 19, no. 2 (2004): 228-53. En adelante Theo. Víctor Choroco, "El argumento de perfección: una respuesta al evolucionismo teísta", Theo 18, no. 2 (2003): 450-75. 


\section{Identidad de Babilonia}

Saber quién será "Babilonia la grande" es muy complejo. Sin embargo, estudiar Ezequiel 16, Isaías 21, Jeremías 51 y las seis veces en que aparece en el libro de Apocalipsis $(14: 8 ; 16: 19 ; 17: 5 ; 18: 2,10$, $21)$, será de gran ayuda. Estos textos permiten identificar esta figura.

(1) "Babilonia la grande", por el contexto escatológico y figurativo en el que aparece (14:8; 17:1-5), es simbólico y no literal. Éste no será el imperio Babilónico antiguo restaurado, como muchos piensan, puesto que no existe en la actualidad. ${ }^{11}$

(2) Babilonia, a lo largo de las Escrituras, siempre ha sido enemiga de Dios y de su pueblo. Fue ella la que llevó cautivo a Israel y profanó el santo templo de Dios tomando los vasos de oro (Dn 1:2). En este sentido, "Babilonia la grande" será un poder que blasfemará contra Dios y oprimirá al remanente $(17: 5,14)$.

(3) EnEzequiel 16, Israel es presentado como "Babilonia"por la apostasía que acarreaba en aquel momento, y es descrito como una prostituta llena dealhajas y de vestidos (vv. 15-18). Esto permite interpretar que "Babilonia la grande", comofigura apocalíptica, representaa un poderpolítico-religioso, ${ }^{12}$ un falso "pueblo de Dios" que está en apostasía. Un sistema que contamina e incita a las naciones impías a rechazar la Palabra de Dios y las promesas divinas.

En conclusión, "Babilonia la grande" representará a toda la "cristiandad" apóstata, incluyendo al poder papal y la iglesia que éste lidera, que estarán en contra del remanente.

${ }^{11}$ Los dispensacionalistas, promotores del rapto secreto, creen que "Babilonia" será una nación restaurada que aparecerá en el futuro (entre ellos, Charles H. Dyer, "The Identity of Babylon in Revelation 17-18", [Th. Master, Dallas Theological Seminary, 1979]; Thomas R. Edgar, "Babylon: Ecclesiastical, Political, or What?", Journal of the Evangelical Theolgical Society 25, no. 3 [1982]: 333-41; Thomas D. Ice, "Babylon in Bible Prophecy", Pre-Trib Research Center, Liberty University [2009]: 1-3). Sin embargo, tal interpretación no respeta la naturaleza simbólica del Apocalipsis. Por esta razón, no se puede aceptar que "Babilonia la grande" será una ciudad literal con ese nombre. Asimismo, en el AT se profetizó que el imperio babilónico "nunca más será poblada [...] y sus días no se prolongarán" (Is 13:19-22; 48:14; Jer 50:2-10).

${ }^{12}$ Hans LaRondelle, "El remanente y el mensaje de los tres ángeles", en Teología: fundamentos biblicos de nuestra fe, ed. Raoul Dederen, trad. David Gullón (Doral, FL: Asociación Publicadora Interamericana, 2008), 8:214; Stefanovic, 448; Fernando Chaij, El drama inminente (Buenos Aires: Asociación Casa Editora Sudamericana, 2001), 122. 


\section{La caída de Babilonia}

La "caída de Babilonia” tiene dos connotaciones en Apocalipsis, y son las siguientes:

(1) Esta caída se refiere a sus actos de inmoralidad (14:8; 17:5; 18:2) e idolatría; las cuales también tienen relación con las verdades bíblicas que están en el Mta y con la misión del remanente. Por un lado, Babilonia embriaga a las naciones con falsas enseñanzas con el objetivo de que éstas no acepten el poder salvífico de Dios y las verdades expresadas en la Biblia; y por otro lado, el remanente testifica para reconocer el poder salvífico de Cristo y las verdades que se encuentran en su Palabra, en especial las que están en el Mta.

(2) Esta caída, según el mensaje del segundo ángel, es un anuncio que profetiza su destrucción total $(16: 19 ; 18: 10,21)$, la cual será realizada en el "juicio a la ramera" (18:21-24). Además, ésta tiene como objetivo indicar que Babilonia está condenada. A pesar de su existencia, ella ya obtuvo la condena eterna y todo aquel que permanezca en ella será destruido (14:10). Es por esta razón que el remanente invita al pueblo de Dios a salir de Babilonia (18:4).

A través del segundo mensaje, el remanente proclama la caída de la gran ramera e invita a los hijos de Dios a salir de ella, con el fin de no seguir contaminándose (Ap 18:4). El remanente no ha de olvidar que ellos también han sido llamados para rescatar al pueblo de Dios invisible de las manos de "Babilonia". Dicha invitación será hecha a través de la proclamación del Mta.

\section{Tercer mensaje angélico (14:9-12)}

En este mensaje se extraen cuatro verdades: (6) la marca de la bestia, (7) los mandamientos de Dios, (8) el testimonio de Jesucristo y (9) el santuario. Éstas han de ser proclamadas por el remanente con un fin preventivo y no condenatorio. 


\section{La marca de la bestia}

El tercer mensaje declara: "no adorar a la bestia" y "no recibir su marca" (v. 9). ${ }^{13}$ ¿En qué consistirá dicha marca o señal? Para responder esta pregunta, se ha de considerar tres puntos importantes: (1) la unidad literaria de Apocalipsis 12 al 14, (2) los textos de Apocalipsis 12:17 y 14:12 que declaran que el remanente "guarda los mandamientos" y "tiene el testimonio", características que distinguen a este grupo y (3) tanto el remanente, la bestia y la marca de ésta aparecen en el mismo contexto escatológico. Con estas tres consideraciones, se llegan a las siguientes conclusiones:

(1) Si los "mandamientos" y el "testimonio" distinguen al remanente, y "la marca" a sus opositores, entonces "la marca" está en oposición o bien a los "mandamientos", al "testimonio" o a ambos.

(2) En las Escrituras, los "mandamientos" ${ }_{14}^{14}$ incluyendo el sábado (Ex 31:13, 17; Ez 20:12, 20), normalmente son considerados como señales; por tanto, en el tiempo del fin, éstos serán lo opuesto a la "marca de la bestia". ${ }^{15}$ Por otra parte, en Apocalipsis 13:14-18 la bestia que sube del mar no batalla contra los diez mandamientos sino principalmente con los cuatro primeros de Éxodo $20 ;{ }^{16}$ por tal motivo, es posible creer que la

${ }^{13}$ La palabra "marca" aparece en el NT tanto en Hechos 17:29 y Apocalipsis 13:16, 17; $14: 9,11 ; 19: 20$, y siempre está relacionado con la idolatría y con la marca de la bestia. En Apocalipsis, esta marca está en un contexto de adoración mundial (13:12-18).

${ }^{14}$ A la luz de Apocalipsis 12 al 14, estos "mandamientos" son los diez de Éxodo 20.

${ }^{15}$ Un estudio sobre la marca de la bestia en Apocalipsis 13:18, está en Mervyn Maxwell, "The Mark of the Beast", en Symposium on Revelation: Introductory and Exegetical Studies-Book 2, ed. Frank Holbrook (Silver Spring, MI: Biblical Research Institute, 1992), 7:41-132; Carlos Olivares, "Elementos para descifrar el 666: una propuesta", DavarLogos 8, no. 1 (2009): 31-58; Enrique Treyer, "Fuego del cielo y marca de la bestia: un estudio exegético de Apocalipsis 13:11-18", Theo 12, no. 2 (1999): 78-101.

${ }^{16}$ Los cuatro primeros mandamientos de Éxodo 20 ordenan: "No tendrás dioses ajenos delante de mí" (v. 3), "No te harás ídolo, ni semejanza [...] ni las adorarás" (vv. 4-5), "No tomarás el nombre de Dios en vano (v. 7)" y "Acuérdate del día de reposo [...]. Seis días trabajarás y harás toda tu obra, mas el séptimo día es día de reposo para el SEÑOR tu Dios; no harás en él obra alguna”. Sin embargo, la primera bestia hace que el mundo lo adore (vv. 5,8$)$ y también blasfema el nombre de Dios (vv. 1, 5-6); además, la segunda bestia manda que los hombres "hagan una imagen de la bestia" (v. 14). Por último, mientras que el Señor decretó no hacer obra alguna en su día, la bestia que sube del mar se atribuye la autoridad divina y prohíbe "comprar ni vender, sino el que tuviese la marca" (v. 17). Todas estas acciones, indican que los secuaces de Satanás irán en contra de los cuatro primeros mandamientos. Anthony MacPherson, "The Mark of the Beast as a 'Sign Commandment' and 
"marca de la bestia" está en oposición a estas cuatro leyes; en especial, por las acciones de la bestia y la alusión al sábado en Apocalipsis 14:7, contra el cuarto mandamiento.

En síntesis, la "marca de la bestia” será una señal espiritual que la recibirán aquellos que estén en oposición a los cuatro primeros mandamientos, principalmente los que estarán en contra del cuarto. Esto implica que la bestia impondrá un falso día de reposo como señal de adoración a ella, a saber, el domingo. Al dejarse marcar, los seguidores de la bestia se someterán a su dominio y decidirán serle fiel; lo que implicará rechazar la ley de Dios y, por ende, su autoridad divina.

Asimismo, el tercer mensaje advierte que aquellos que decidirán tener la "marca" serán castigados con la "ira de Dios" (14:10), enfatizando así las consecuencias de aceptar esta marca.

El remanente, conociendo que este mensaje es para el futuro y no necesariamente para el presente, ${ }^{17}$ debe continuar proclamando este mensaje con un fin preventivo y no condenatorio. El énfasis de esta verdad es darle el debido lugar a la ley de Dios y no condenar a los que la rechazan.

\section{Los mandamientos de Dios}

Según Apocalipsis 12:17 y 14:12, el remanente "guarda los mandamientos de Dios". Por lo registrado, el remanente posee esta verdad. Pero ¿a qué mandamientos se refieren? Indiscutiblemente a los diez de Éxodo $20 .{ }^{18}$ Esto implica que el remanente, en el tiempo del fin, invitará a todo ser humano a aceptar y a obedecer la ley divina. Dicha invitación y observancia, por lo menos, implica cuatro puntos importantes:

\footnotetext{
'Anti-Sabbath' in the Worship Crisis of Revelation 12-14", Andrews University Seminary Studies 43, no. 2 (2005); Jon Paulien, "Revisiting the Sabbath in the Book of Revelation", JATS 9, no. 1-2 (1998): 179-86.

${ }^{17}$ Cuando se menciona que este mensaje es para el futuro y no necesariamente para el presente, es porque lo registrado en Apocalipsis 13:14-18, el contexto de la marca de la bestia, aún no se ha cumplido. Tanto las acciones de la bestia que sube de la tierra, la marca de la bestia y la persecución final son acontecimientos futuros. No obstante, los sucesos que están ocurriendo a lo largo del planeta determinan que éstos sucederán muy pronto.
}

${ }^{18}$ Después de analizar el término mandamiento y de estudiar el contexto de Apocalipsis 12 al 14, se llegó a esta conclusión. Para un mayor estudio, ver Mendoza, “Alusiones al sábado", 190-2. 
(1) La ley de Dios se convertirá en el blanco de ataque de Satanás y en el centro de la controversia final. Sin embargo, como se ha visto, no todos los mandamientos estarán inmersos en este conflicto, al revisar los capítulos 13 y 14, los cuatro primeros serán el centro de ataque de la bestia que sube del mar y de la bestia que sube de la tierra, especialmente el cuarto.

(2) El decálogo nunca fue abolido ni en la cruz ni en algún otro lugar o momento, mucho menos por alguna persona. Apocalipsis 12:17 y 14:12 son textos explícitos que indican la existencia de la ley en el tiempo del fin. Si éstos fueron abolidos en la cruz, entonces, ¿Por qué fueron mencionados y profetizados en el libro de Apocalipsis?

(3) La ley es el reflejo del carácter de Dios: el amor (Ro 13:8-10). Al guardarlos, el remanente manifiesta el amor a su Señor y a todas las naciones.

(4) La observancia de los mandamientos son los frutos de la fe. Puesto que los hijos de Dios fueron justificados al haber aceptado el "evangelio eterno", ahora ellos guardan la ley. Por lo tanto, el pensamiento "una vez salvo por la cruz siempre salvo", a la luz del Mta, no es aceptable. La observancia de la ley divina indica cómo vive un justo.

En conclusión, los “mandamientos de Dios" son los diez de Éxodo 20 y cumplirán un papel preponderante en la crisis venidera. Éstos no fueron abolidos ni en la cruz ni en algún otro lugar; no obstante, en el contexto de Apocalipsis 13, la bestia que sube del mar intentará eliminarlos con el objetivo de no adorar a Dios pero sí a ella misma.

El remanente, guardando los mandamientos de Dios, testifica la necesidad de verdaderos adoradores y restaurando la ley divina. En la crisis final se necesitará ser fiel y leales a nuestro Dios. Precisamente, dicha lealtad se dará observando sus mandamientos.

\section{Fe en el testimonio de Jesucristo}

Apocalipsis 12:17 registra que el remanente tiene el testimonio de Jesús. Pero, ¿Qué es el testimonio de Jesús? Para responder a esta pregunta, se relacionará Apocalipsis 12:17, 14:12, 19:10 y 22:8-10. 
(1) Por un lado, en 12:17 el remanente tiene el testimonio de Jesús, por otro lado, en 14:12, los santos guardan la fe de Jesús. Al hacer el paralelismo entre ambos textos, se nota que testimonio va en paralelo con $f e$. Esta relación, más que enfatizar distintas características del remanente, indican la fe del remanente en el testimonio.

(2) Este testimonio, según 19:10, es definido como el Espíritu de profecía, el cual está en paralelo con profetas de 22:8-9. ${ }^{19}$

(3) El Espíritu de profecía, es el mismo Espíritu Santo dando el don profético a las personas que son llamadas profetas (1 Co 12:8, 10).

El testimonio de Jesucristo es la revelación de Jesús dada a los profetas en el NT. Éste incluye las verdades bíblicas enseñadas y confirmadas por Jesús cuando estuvo en la tierra. ${ }^{20}$ No obstante, no sólo el NT trata acerca de Jesucristo, el Espíritu de Profecía también profetizó de Él en el AT. En Apocalipsis no se usa los términos "AT" para referirse a las profecías mesiánicas dadas por los profetas, más bien, se utiliza la expresión "Palabra de Dios" para referirse a lo mismo. Hablar de la "Palabra de Dios" es hablar del testimonio del AT. ${ }^{21}$

${ }^{19}$ Lo que se acaba de definir es muy importante. Algunos creen que el "testimonio de Jesucristo" de Apocalipsis 12:17 es el "evangelio eterno". No obstante, al analizar el "testimonio de Jesucristo", tal interpretación no es aceptable. El énfasis de la segunda característica del remanente es que éste tiene o posee aquel "testimonio" y no que lo predica o lo proclama. Además, como se acaba de ver, existe una definición explícita en 19:10, paralelamente con 22:8-10 (para un mayor estudio, ver Gerald Pfandl, "The Remnant Church and the Spirit of Prophecy", en Symposium on Revelation-libro 2, ed. Frank B. Holbrook [Silver Spring, MI: Biblical Research Institute, 1992], 7:304-6). Creer que el "testimonio de Jesús" es el "evangelio" es limitarse únicamente en la "salvación" y dejar de lado otras verdades que enseña la Palabra de Dios. Al respecto, Fernando Canale señala, "por eso, las verdades bíblicas no pueden limitarse a Dios y la salvación, como parecen sugerir otros modelos, sino que abarcan la sorprendente diversidad de verdades relacionadas entre sí en cuanto a Dios y sus obras. Los exégetas y los teólogos deben tener especial cuidado de no ahogar esta riqueza diciendo unilateralmente que solo son relevantes ciertas verdades salvíficas, descartando el resto. Obrar así pondría a los teólogos en un empeño reductor y distorsionador de la 'esencia' del mensaje cristiano, descartando la mayoría de las enseñanzas cristianas como si estuviesen condicionadas culturalmente y resultasen, por lo tanto, prescindibles". Fernando Canale, "Revelación e Inspiración", en Entender las sagradas Escrituras: un enfoque adventista, ed. George Reid (Doral, FL: Asociación Publicadora Interamericana, 2006), 88-9.

${ }^{20} \mathrm{E}$ testimonio de Jesús de Apocalipsis 12:17 no sólo incluye lo que está escrito en la Biblia, sino también la existencia de un profeta en el tiempo del fin. Por lo registrado, el remanente tendrá el don profético en sus filas. Dicho don, según la Iglesia Adventista del Séptimo Día, lo recibió Elena de White. El autor está de acuerdo con tal afirmación.

${ }^{21}$ Hans LaRondelle, "La palabra de Dios y el testimonio de Jesucristo", Ministerio Adventista 322, no. 06 (2006), 26. 
Por lo tanto, el remanente, al poseer el Espíritu de profecía, acepta y cree lo que los profetas escribieron en las Escrituras. En otras palabras, este grupo escatológico es fiel a lo que está escrito en la Biblia. Por ejemplo, si las Escrituras anunciaron la perpetuidad de los mandamientos (Mt 5:17; Ro 3:31; 13:8-10; Stg 2:10; Ap 12:17), el remanente cree y los guarda. Si los profetas declararon la divinidad (Jn 1:1, 14, 18; Heb 1:8), humanidad (Fil 2:5-8) y el mesianismo de Jesucristo (Jn 1:11, 4:25, 26), el remanente no rechaza esta verdad, al contrario, la acepta como profesión de fe. Si los siervos de Dios expusieron que el sábado es el día de reposo (Is 58; Mr 2:27-28), el remanente escatológico observa este mandamiento y no lo abole. Si la Biblia describe la 2 da venida de Cristo como visible y gloriosa (1 Tes 4:13-18; Ap 1:7), el pueblo de Dios del tiempo del fin proclama este evento y no la tergiversa.

En el tiempo escatológico, en una época donde se desconfía de la Biblia y las verdades que están en ella son pisoteadas, e inclusive reinterpretadas, el mensaje del tercer ángel es claro: "Confíen en la Palabra de Dios. No rechacen ni distorsionen lo que ella enseña. La verdad fue relevada a los profetas y está en las Escrituras. Más bien, no acepten ninguna falsa enseñanza de Babilonia. Cualquier palabra o imposición de ella no son autoritativas y normativas sino sólo lo registrado en la Biblia".

Para un buen cumplimiento de la misión, el remanente debe continuar guiando al mundo a la Biblia, y sólo a ella.

\section{El santuario}

A pesar que esta verdad no es explícita en el Mta, el santuario celestial (cf. Ap 11:19; 15:5-8) es el marco de referencia de los capítulos 12 al 14. Por lo tanto, todas las verdades proclamadas por los tres ángeles están vinculadas a este lugar. Esta relación se ha venido dando desde los días de Moisés. Desde la antigüedad, Dios enseñaba las verdades que Él quería que su pueblo aprenda a través del santuario. ${ }^{22}$

${ }^{22}$ Antes de la inauguración del santuario terrenal, fueron los "altares", edificados por los patriarcas (Gn 8:20; 12:7, 8; 35:7; Éx 17:15), los que enseñaban el plan de salvación. Para un mayor estudio sobre el altar en el Pentateuco y su significado para el NT, ver Raúl Quiroga, "El binomio altar/sacrificio como centro teológico del Pentateuco y su significado y simbolismo para el Nuevo 
Se presentan cuatro ejemplos: $:^{23}$

(1) El santuario y el evangelio: por medio de la sangre de los animales y de la intercesión sacerdotal en el santuario, Dios expiaba a su pueblo ( $\mathrm{Lv}$ 16:16). Aquella expiación tenía como objetivos la purificación de los pecados y la justificación/salvación del ser humano. A través de este acto, el hijo de Dios era partícipe de la verdad del evangelio.

(2) El santuario y el juicio. Era desde el santuario terrenal donde Dios emitía sus juicios (Nm 13:32; 14:2, 10; Sal 9:7, 8).

(3) El santuario y la ley. Las tablas de la ley fueron guardadas en el lugar santísimo, específicamente en el arca del pacto (Éx 25:10-21).

(4) El santuario y Dios. Era en este lugar donde Dios se presentaba a su pueblo y era adorado por ser el Creador y el Redentor (Éx 5:15).

A través de estos ejemplos, se observa que varias verdades fueron enseñadas por Dios a través del santuario. ${ }^{24}$ Por tanto, como el santuario terrenal (tipo) fue sombra del celestial (anti-tipo), las verdades bíblicas que están en el Mta deben ser enseñadas a la luz del santuario celestial y la labor sumo sacerdotal de Jesucristo. Rechazar el santuario es "romper la médula espinar" de la Palabra de Dios; lo que generaría confusión y distorsión del plan de salvación.

Por otra parte, enseñar sobre el santuario es vital para la redención del ser humano. Todas las naciones necesitan saber que existe un lugar donde Dios está salvando al pecador. En dicho lugar nuestro Sumo Sacerdote Jesucristo está intercediendo por nosotros (1 Ti 2:5) ante el Padre

Testamento", $V L O, 375-88$.

${ }^{23}$ Otro ejemplo, de los varios que existen, es la relación entre el santuario y el sábado. A través de las invitaciones hechas por Dios en las distintas fiestas (cuyo día central era el séptimo día; ver Éx 12:16) desde su santuario y celebradas por Israel, los judíos comprendían mejor la naturaleza del sábado y su relevancia.

${ }^{24}$ Varios eruditos han concluído que el Señor enseñaba el plan de salvación y otras verdades bíblicas a través del santuario. Al respecto, Jirí Moskala indica lo siguiente: "Todos los servicios en el santuario fueron una lección objetiva del plan de redención de Dios. Allí Dios explicaba cómo trataba con el pecado y revelaba cómo él salvaba a su pueblo". Jirí Moskala, "The Message of God's People in the Old Testament", JATS 19, no. 1-2 (2008): 18-39. Ver también Clifford Goldstein, Desequilibrio fatal: la verdad acerca del juicio, el santuario y la salvación, trad. Mario A. Collins (Buenos Aires: Asociación Casa Editora Sudamericana, 1995), 72; Roy Adams, El santuario, trad. Félix Cortés V. (Doral, FL: Asociación Publicadora Interamericana, 1998). 
con el fin de expiar nuestros pecados (1 Jn 2:1; Heb 2:18; 4:16), y así ser declarados justos como si nunca hubiésemos pecado.

A través de este mensaje, el remanente anuncia al mundo que existe un lugar de eterna redención en el cielo, y éste es el santuario celestial.

\section{Implicancias de las nueve verdades}

Para esta sección, basándose al siguiente diagrama, se estudiarán las implicancias de las nueve verdades extraídas del Mta.

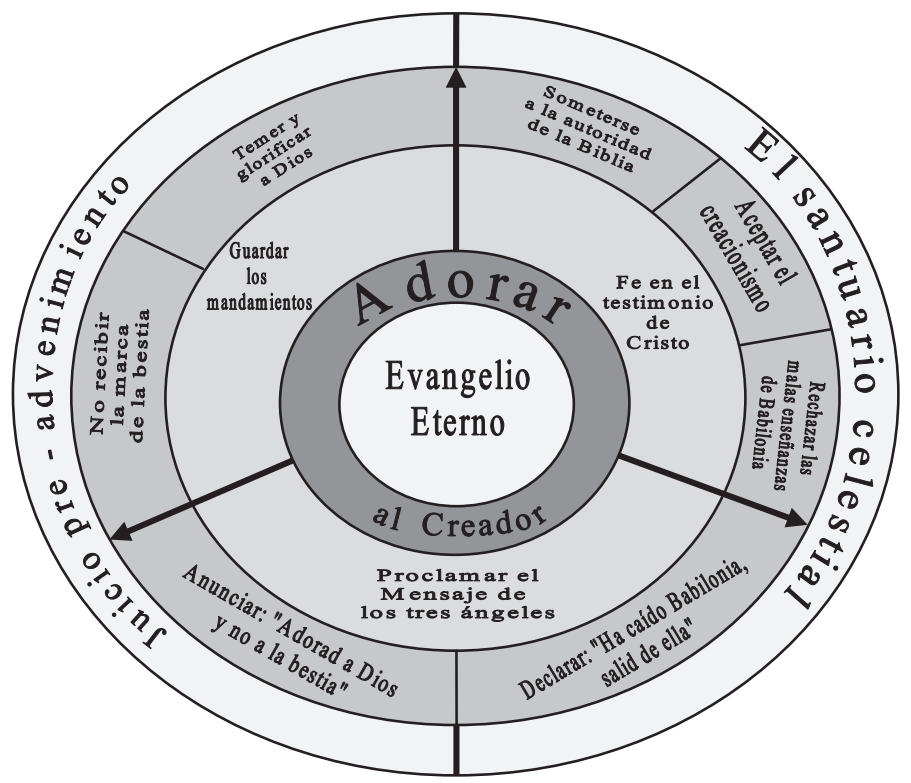

(1) El mensaje central del Mta es el "evangelio eterno". Por lo tanto, cualquier verdad predicada en el tiempo del fin debe tener como base la justificación por la fe.

(2) Aquella persona que ha sido justificada, adorará al Creador 
como respuesta a este acto redentor. Esto implica que las acciones salvíficas y creadoras de Dios requieren una respuesta del ser humano, a saber, a través de la adoración.

(3) Aquella adoración, en el tiempo del fin, implica: (a) guardar los "mandamientos de Dios", (b) tener fe en las Escrituras y (c) proclamar el Mta. En todas las edades, especialmente en el tiempo del fin, adorar a Dios ha requerido observar su ley, considerar su Palabra como regla de fe y cumplir la misión encomendada. No se puede hablar de adoración sino existen estos tres elementos.

(a) Guardar la ley (diez mandamientos) involucra dos puntos:

(a.1.) Temed y dadle gloria al Creador. Estas acciones implican la reverencia y las buenas obras de parte del justificado; en este sentido, el llamado del remanente no es sólo para aceptar el evangelio, sino también invita a un cambio de vida, una vida de obediencia y respeto al Señor.

(a.2.) Rechazar la marca de la bestia. Cuando la bestia que sube del mar imponga su marca, el justificado la rechazará puesto que observa los primeros cuatro mandamientos, especialmente el cuarto.

(b) Tener fe en el "testimonio de Cristo" implica:

(b.1.) Someterse a la autoridad de la Biblia. Esta actitud exige interpretar correctamente la Palabra de Dios, aceptar y practicar lo que en ella está escrito y enseñar con un "Escrito está". 25

(b.2.) Aceptar el creacionismo. Se acepta esta verdad porque con ella se confiesa las acciones creadoras y redentoras de nuestro Señor, se anula cualquier pretensión de adoración por algún ser creado y desenmascara muchas enseñanzas falsas de Babilonia. ${ }^{26}$

\footnotetext{
${ }^{25}$ No hay duda, para que las bestias de Apocalipsis 13 engañen a los moradores de la tierra, éstas distorsionarán lo que está escrito en la Palabra de Dios y engañarán con falsas creencias. El único propósito de estas acciones será quitarle toda la autoridad a la Biblia.
}

${ }^{26}$ Como por ejemplo la vida después de la muerte, la observancia del día domingo, adorar $a$ 
(b.3.) Rechazar las falsas enseñanzas de Babilonia. Todo lo que proclama este poder no es bíblico, por tanto, tiene que ser rechazado; para ello, un estudio concienzudo de la Biblia permitirá tener un espíritu de discernimiento de lo que es verdadero y de lo que es falso.

(c) Proclamar el Mta involucra:

(c.1.) Anunciar “Adorad al Creador y no a la bestia”. Lo que implica un llamado de elección, o bien el ser humano adora a su Creador y Redentor y así obtiene la vida eterna, o adora a la bestia y a su imagen consiguiendo así la muerte eterna. (c.2.) Declarar "Ha caído Babilonia, salid de ella". Para ello, se necesita conocer las verdades que enseña las Escrituras con el propósito de denunciar la "fornicación" de la "gran ramera" e invitar al "pueblo de Dios" (18:4) a salir de allí con el objetivo de "adorar al Creador" y "vivir en la verdad".

(4) Las verdades proclamadas en el Mta tienen que ser enseñadas a la luz del "juicio pre advenimiento" y del "santuario". Por ejemplo, si se desea hablar sobre el "evangelio eterno", se ha de considerar el "juicio pre advenimiento", puesto que en éste, que viene desarrollándose en el santuario celestial, se justifica al ser humano pecador y se salva a los hijos de Dios, porque es a favor de los santos (Dn 7:22). Por tanto, el juicio proclamado por el primer ángel se convierte en una buena noticia para todo aquel que desea obtener la salvación. De igual manera, si se quiere invitar a "adorar al Creador" y a "temed y dadle gloria", se tiene que hacer sin olvidar la razón de dicho llamado: "la hora de su juicio ha llegado" (v.7). Asimismo, si se va a enseñar los "mandamientos de Dios", también se ha de considerar el "juicio", puesto que el Señor Jesucristo cuando deje de interceder por nosotros y venga a la tierra, vendrá como Juez y, en su 2da venida, "pagará a cada uno conforme a sus obras" (Ro 2:5-6). ${ }^{27}$

muchos dioses, el hombre vino producto de la evolución, la ley fue abolida, etc.

${ }^{27}$ Aun hay más ejemplos en el Mta: (1) el juicio a la ramera ("ha caído Babilonia"); (2) la ira de Dios sobre los que tienen la marca de la bestia ("beberá del vino de la ira de Dios", vv. 10- 
Después de ver las implicancias de las nueve verdades del $M t a$, se percibe lo importante que es estar bien preparados en el tiempo del fin. En estos tiempos, cuando la Biblia es "pisoteada" y los libros proféticos de Daniel y Apocalipsis son mal interpretados, Dios pide, a través de Apocalipsis 14:6-12, un estudio mucho más abarcante y sólido acerca de las profecías y de los eventos que vendrán. Esto ayudará a cumplir la misión que el Señor ha encomendado: proclamar el Mensaje de los tres ángeles. Al respecto, George Knight señala, "el adventismo se fortaleció proclamando que tenía un mensaje profético para nuestro tiempo. Y ese mensaje, remozando para el siglo XXI, dará fuerza al adventismo tanto en el presente como en el futuro". ${ }^{28}$

\section{Conclusión}

(1) De Apocalipsis 14:6-12 se extraen nueve verdades bíblicas básicas que son proclamadas en el tiempo del fin: la justificación por la fe, la santificación, el juicio pre advenimiento, el creacionismo, la caída de Babilonia, la marca de la bestia, los mandamientos de Dios, la fe en el testimonio de Jesucristo y el santuario.

(2) Estas nueve verdades giran en torno al evangelio eterno. Si se va a predicar sobre la ley de Dios, se debe de hacer teniendo como base el evangelio. Si se quiere enseñar sobre la marca de la bestia o la caída de Babilonia, se debe enseñar a la luz del evangelio. Si se va a proclamar sobre el sábado o el juicio, de igual modo. Toda verdad, sea cual fuere, debe de tener como centro lo siguiente: "Dios salvando al ser humano".

(3) A través de estas verdades bíblicas se observa el empeño de Dios por salvar a la humanidad. No sólo el "amor de Dios" guarda relación con la salvación; también están los mandamientos, la fe en el "testimonio de Jesucristo", la creación, el santuario, la advertencia a no tener

\footnotetext{
11), etc. Todos estos ejemplos revelan la importancia de proclamar el Mta a la luz del "juicio pre advenimiento" y del "santuario celestial".

${ }^{28}$ George Knight, La visión apocalíptica y la castración del adventismo (Florida: Asociación Publicadora Interamericana, 2009), 22.
} 
la marca de la bestia y salir de Babilonia, el juicio pre-advenimiento, etc. Todas estas verdades están direccionadas para la redención final del hombre.

(4) Dios invita a sus hijos a predicar el Mta. A cumplir la misión de forma completa y de manera imparcial. 